\title{
Synthesis, Spectral Characterization and Antimicrobial Activities of Ethyl-2-(4-(naphthalene-1-yl)-6-phenyl- pyrimidin-2-yl amino)acetate Derivatives
}

\author{
C. RAJA ${ }^{1}$, M R. EZHILARASI $^{1}{ }^{*}$, B. PRABHA ${ }^{1}$ and M. KULANDHAIVEL ${ }^{2}$ \\ ${ }^{1}$ Department of Chemistry, Karpagam University, Coimbatore-21, Tamilnadu, India \\ ${ }^{2}$ Department of Micro-Biology, Karpagam University, Coimbatore-21, Tamilnadu, India \\ mrezhilarasi@gmail.com
}

Received 5 April 2017 / Accepted 1 May 2017

\begin{abstract}
The novel series of ethyl-2-(4-naphthalene-1-yl)-6-phenyl pyrimidin-2-yl amino)acetate derivatives were synthesised by the condensation reactions of 4-(naphthalene-1-yl)-6-phenyl pyrimidin-2-amines reacted with chloroethyl acetate and $\mathrm{K}_{2} \mathrm{CO}_{3}$ as a catalyst. The 4-(naphthalene-1-yl)-6-phenyl pyrimidin-2-amines were occurred by the reaction between naphthalene chalcones and guanidine nitrate in the presence of ethanolic sodium hydroxide solution. The naphthalene chalcones were synthesised from substituted aldehydes treated with 1-acetyl naphthalene. Finally the synthesised compounds were determined by elemental analysis and spectral characterizations such as FT-IR, ${ }^{1} \mathrm{H}$ NMR and ${ }^{13} \mathrm{C}$ NMR. The antimicrobial activities of the new synthesised heterocyclic compound are evaluated against gram positive, gram negative bacterial and fungal strains. The electron withdrawing chloro substituted derivative have an excellent zone of inhibition against bacterial strains.
\end{abstract}

Keywords: Naphthalene chalcone, Chloroethyl acetate, Guanidine nitrate, $\mathrm{K}_{2} \mathrm{CO}_{3}$ Antimicrobial activity

\section{Introduction}

Sulphur and nitrogen containing heterocyclic compounds are exhibit good biological activities. NMR spectroscopy is a good tool for providing information about structure of the heterocyclic compounds. Chalcone is one of the major classes of natural products. It possess several biological activities such as antibacterial ${ }^{1-2}$, anti-fungal ${ }^{3-4}$ and anti-tumour activities ${ }^{5-6}$. The pyrimidine derivatives are also known to exhibit diverse pharmacological properties such as effective bactericides and fungicides ${ }^{7}$. The 2-aminopyrimidine structural unit is present in a growing number of both natural products and synthetic compounds with biological properties of particular interest ${ }^{8}$. Pyrimidine compounds are useful drugs which are associated with many biological and therapeutical activities. They can be reported as anti-tumour $^{9}$ and used as hypnotic drugs for the nervous system ${ }^{10}$. It exhibits the cardioprotective effects ${ }^{11}$. It is revealed from the literature review the pyrimidine derivatives 
found to posses biological activities known as fungicidal ${ }^{12-13}$, analgesic ${ }^{14}$ and antimicrobial ${ }^{15}$. The substituted amino pyrimidine structures are common in marketed drugs such as aronixil, thonzylamine ${ }^{16}$ Figure 1 .<smiles>Cc1cccc(Nc2cc(Cl)nc(NCC(=O)O)n2)c1C</smiles>

Aronixil<smiles>COc1ccc(CN(CCN(C)C)c2ncccn2)cc1</smiles>

Thonzylamine

Figure 1. Structure of aronixil and thonzylamine

The substituted amino acetate derivatives show good biological activities. Our synthesized compounds were subjected against three microbial organisms (Staphylococcus epidermidis, Pseudomonas aeruginosa and Candida albicans), here ciprofloxacin used as a standard drugs. Owing to the documented biological properties of amino acetate derivatives, herein we report the continuation of our work a series of new amino acetate were designed, synthesized by using chloroethyl acetate, potassium carbonate used as a catalyst and their antimicrobial activities were evaluated in vitro.

\section{Experimental}

The melting points of the compounds were determined in open capillaries and are uncorrected. Purity of the compounds was checked by TLC on silica gel plate. The FT-IR spectrum $\left(\mathrm{cm}^{-1}\right)$ of the compounds were recorded using $\mathrm{KBr}$ on a Fourier Transform IR spectrometer (model Shimadzu 8400s) in the range of 400-4000 $\mathrm{cm}^{-1}$. ${ }^{1} \mathrm{H}$ NMR spectra were recorded in Bruker $500 \mathrm{MHz}-\mathrm{NMR}$ spectrometer (Astra Zeneca India Ltd) using $\mathrm{CDCl}_{3}$ as a solvent and chemical shifts $(\delta)$ values are reported in parts per million.

\section{General procedure for synthesis of chalcones}

The one mole of 1-acetonaphthanone and one mole of various substituted aldehydes were taken in a beaker and to this approximately added $30 \mathrm{~mL}$ of ethanol containing $2 \mathrm{~g}$ of $\mathrm{NaOH}$ pellets. This mixture was stirred well for 30 minutes in an ice cold bath then it was poured into the crushed ice and this reaction mixture was kept into overnight at room temperature. The chalcones were precipitated out as solid. Then it was filtered. Dried and recrystallized from ethanol. The purity of the sample was checked by TLC by using chloroform as the solvent.

Synthesis of 4-(naphthalene-3-yl)-6-phenyl-pyrimidin-2-amines (4a-f)

A mixture of various substituted naphthalene chalcones (1 mmol), Guanidine nitrate (1 mmol), $25 \mathrm{~mL}$ of ethanol and a $10 \mathrm{~mL}$ of $10 \%$ solution of sodium hydroxide were added portion wise for 2 hours. Then the reaction mixture was shaken well and it was refluxed for 12-14 hours. The reaction was monitored by TLC. After the reaction mixture was cooled at room temperature and poured into crushed ice, the white precipitate was obtained. Finally the precipitate was filtered, dried and recrystallized from ethanol.

\section{Ethyl-2-(4-(naphthalene-1-yl)-6-phenylpyrimidin-2-yl amino) acetate (5a-5f)}

The 4-(naphthalene-1-yl)-6-aryl-pyrimidin-2-amines (1 mol), chloroethyl acetate, potassium carbonate and toluene $(25 \mathrm{~mL})$ is taken in a round bottom flask, the mixture was shaken well 
and then it was refluxed for 4-6 h. The completions of the reactions were monitored by TLC. After the reaction mixture was cooled to room temperature and poured into crushed ice, the white precipitate was obtained. After filtration the precipitate was recrystallized from ethanol. The physical and analytical values of the synthesized compounds (3a-5f) are shown in Table 1.
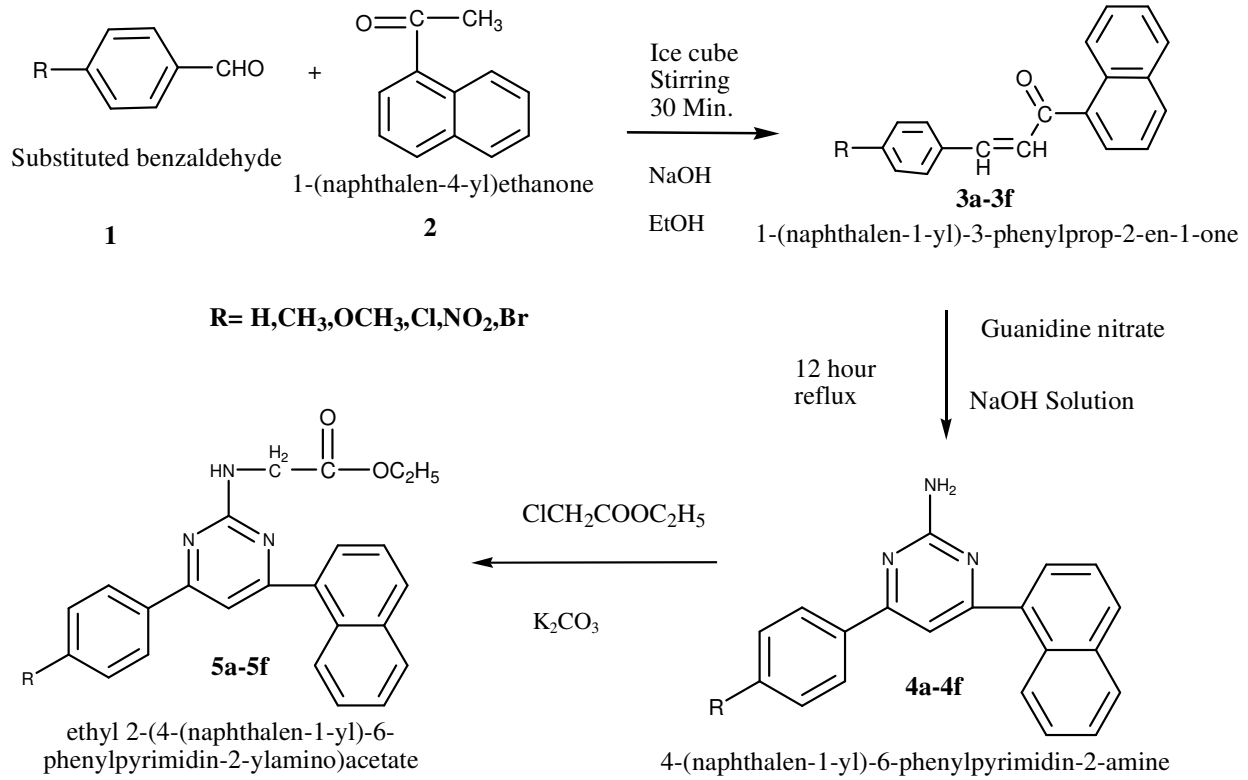

Scheme 1. Synthesis pathway of compounds 5a-5f

\section{Antimicrobial studies}

The synthesized compounds 5a-5f screened against the anti-bactrial strains such as Staphylococcus epidermis, Pseudomonas aurgeinosa and the fungal strain like Candida albicans. The antimicrobial studies are carried out by the literature survey method ${ }^{17}$.

Table 1. Physical and analytical data of the synthesized compounds (3a-5f)

\begin{tabular}{|c|c|c|c|c|c|}
\hline No & $\begin{array}{l}\text { Structure of the } \\
\text { compound }\end{array}$ & $\begin{array}{l}\text { Molecular } \\
\text { formula }\end{array}$ & $\begin{array}{c}\text { Molecular } \\
\text { weight }\end{array}$ & $\begin{array}{l}\text { Melting } \\
\text { point }\end{array}$ & $\begin{array}{l}\% \text { of } \\
\text { yield }\end{array}$ \\
\hline $3 a$ & & $\mathrm{C}_{19} \mathrm{H}_{14} \mathrm{O}$ & 258 & 102 & 82 \\
\hline $3 b$ & & $\mathrm{C}_{20} \mathrm{H}_{16} \mathrm{O}$ & 272 & 124 & 92 \\
\hline $3 c$ & & $\mathrm{C}_{20} \mathrm{H}_{16} \mathrm{O}_{2}$ & 288 & 88 & 90 \\
\hline
\end{tabular}




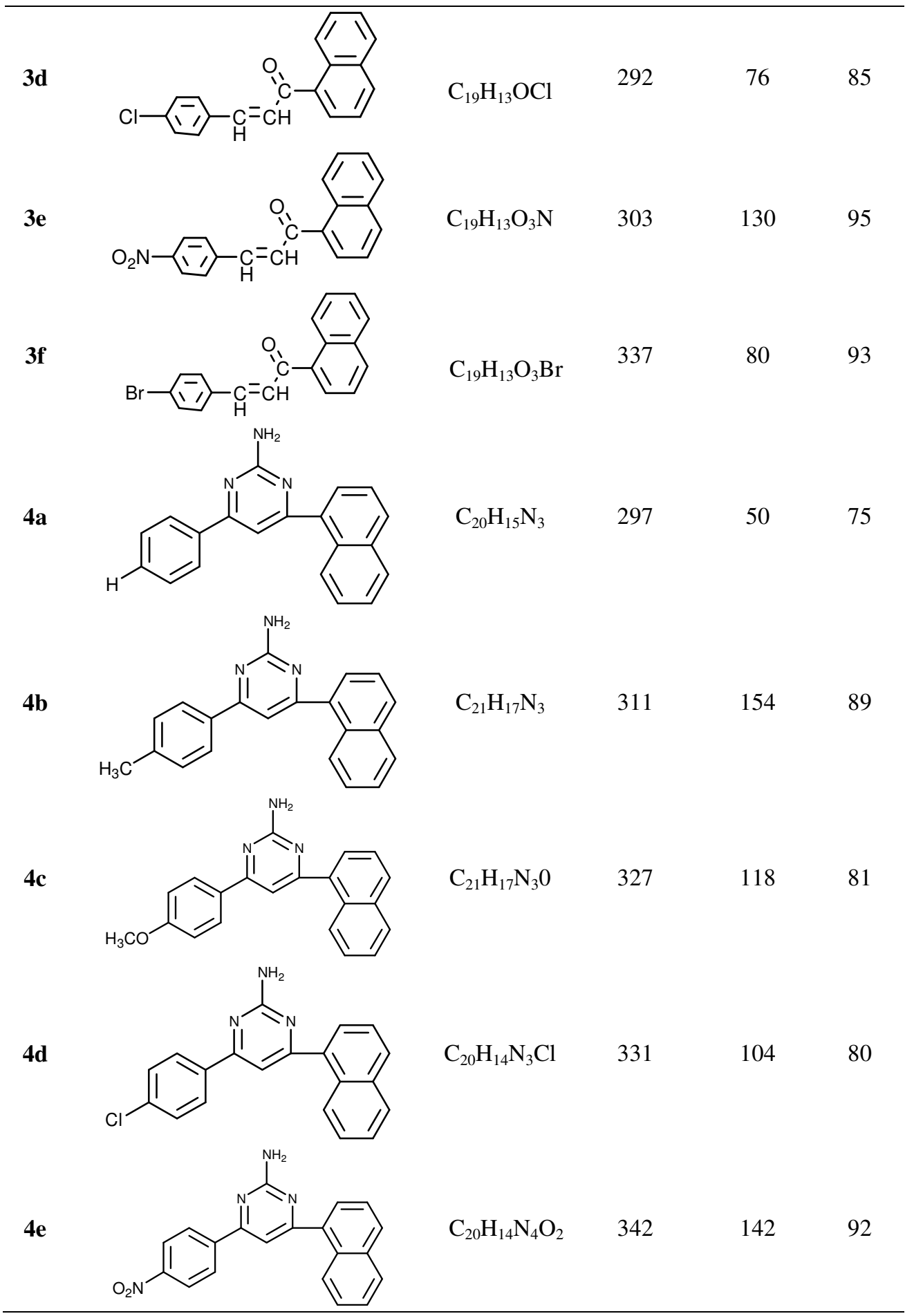




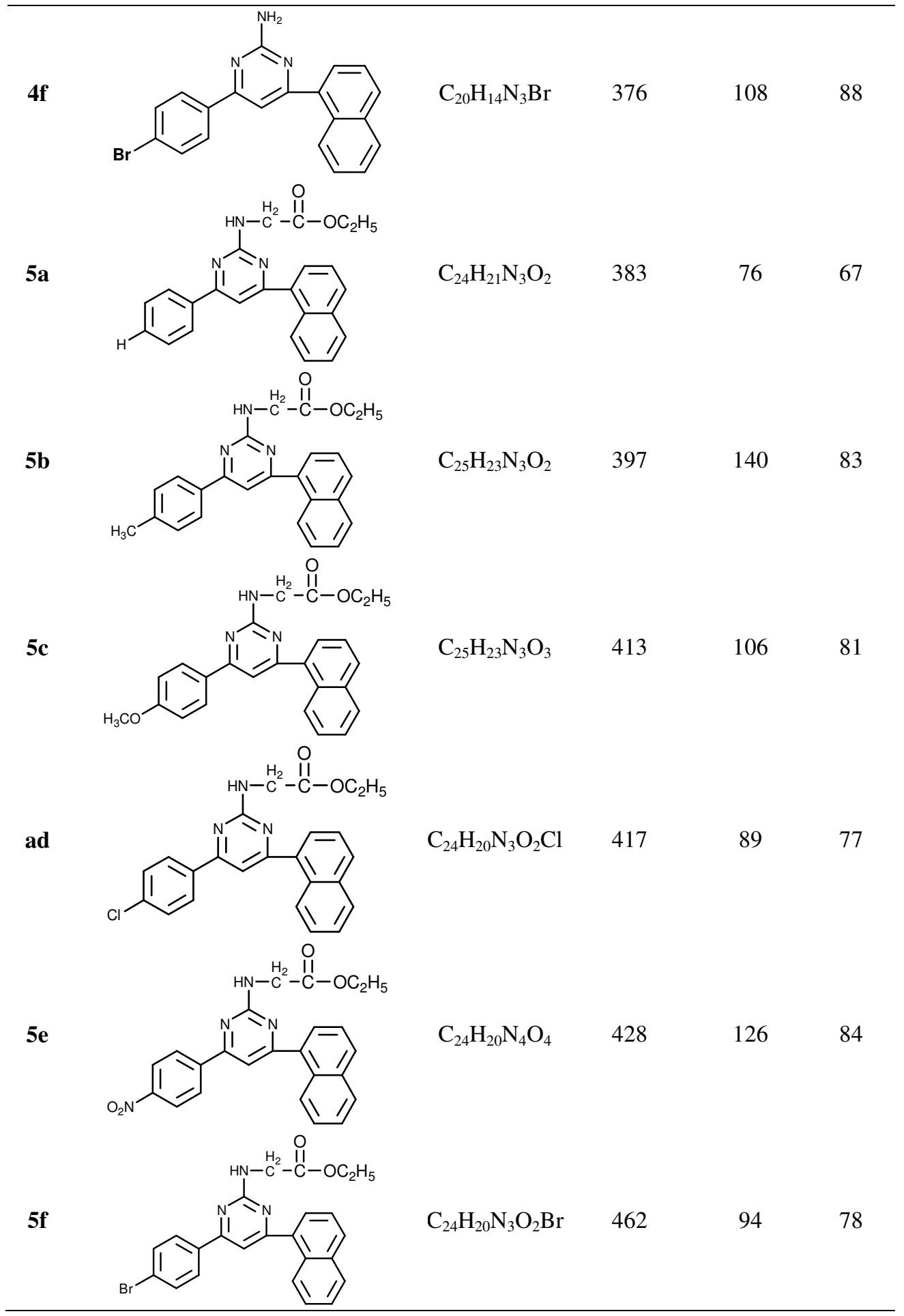




\section{Results and Discussion}

The ethyl-2-(4-naphthalen-1-yl)-6-phenylpyrimidin-2-ylamino)acetate were synthesized from 4-(naphthalene-1-yl)-6-phenylpyrimidin-2-amine react with chloroethyl acetate and potassium carbonate used as a catalyst. The skeleton structure of the synthesized compounds characterized by using IR, ${ }^{1} \mathrm{H}$ NMR and ${ }^{13} \mathrm{C}$ NMR. The 4-(naphthalene-1-yl)-6phenylpyrimidin-2-amines were synthesized from the naphthalene-1-yl chalcones react with guanidine nitrate in the presence of base solution.

\section{Spectral analysis}

\section{FT-IR analysis of the synthesized compounds}

The IR spectrum of the compounds (3a-3f) shows that the characteristic bands at 1645 to $1655 \mathrm{~cm}^{-1}$ due to the presence of $\mathrm{C}=\mathrm{O}$ stretching frequencies. The absorption bands around 1570 to $1600 \mathrm{~cm}^{-1}$ attributed to the presence of $\mathrm{C}=\mathrm{C}$ stretching frequencies. The aromatic $\mathrm{CH}$ stretching frequencies appeared in the range of 3000 to $3100 \mathrm{~cm}^{-1}$ and aliphatic $\mathrm{CH}$ stretching frequencies appeared in the range of 2900 to $3000 \mathrm{~cm}^{-1}$. The IR spectrum of the 3a-3f compounds are shown in Table 2 . The IR spectrum of the compounds $(\mathbf{4 a - 4 f})$ revealed a sharp strong absorption band above $1610 \mathrm{~cm}^{-1}$ that can be attributed with the presence of the $\mathrm{C}=\mathrm{N}$ stretching. The aromatic $\mathrm{CH}$ asymmetric and symmetric stretching vibration in the structure of pyrimidine nucleus around $3150 \mathrm{~cm}^{-1}$ and for the aliphatic $\mathrm{CH}$ group showed a sharp absorption band around $2900 \mathrm{~cm}^{-1}$ and another sharp strong absorption band was noticed at around $1560 \mathrm{~cm}^{-1}$ for $\mathrm{C}=\mathrm{C}$ group and the stretching frequency for $\mathrm{C}-\mathrm{N}$ group obtained $1350 \mathrm{~cm}^{-1}$. The IR spectrum values of the compounds $\mathbf{4 a - 4 f}$ shown in Table 3 .

Table 2. The IR spectrum values of compounds 3a-3f

\begin{tabular}{|c|c|c|c|c|c|}
\hline Compound & $\begin{array}{c}\mathrm{C}=\mathrm{C} \\
\text { Stretching } \mathrm{cm}^{-1}\end{array}$ & $\begin{array}{c}\mathrm{C}=\mathrm{O} \\
\text { Stretching cm}{ }^{-1}\end{array}$ & $\begin{array}{c}\text { Aromatic CH } \\
\text { Stretching cm }\end{array}$ & $\begin{array}{c}\text { Aliphatic CH } \\
\text { Stretching cm }\end{array}$ & $\begin{array}{l}\text { Aromatic ring } \\
\text { Stretching } \mathrm{cm}^{-1}\end{array}$ \\
\hline $3 a$ & 1602.85 & 1651.07 & 3051.39 & 2953.02 & $\begin{array}{l}813.36 \\
750.31 \\
706.96\end{array}$ \\
\hline $3 b$ & 1593.20 & 1660.71 & 3059.10 & 2906.73 & $\begin{array}{l}752.24 \\
815.83\end{array}$ \\
\hline $3 c$ & 1597.06 & 1654.92 & 3051.39 & $\begin{array}{l}2991.59, \\
2953.02\end{array}$ & $\begin{array}{l}815.83 \\
759.95 \\
746.45\end{array}$ \\
\hline 3d & 1597.06 & 1664.57 & 3059.10 & 2927.94 & $\begin{array}{l}819.75 \\
756.10 \\
705.95\end{array}$ \\
\hline $3 e$ & 1600.92 & 1660.71 & 3055.24 & 2924.59 & $\begin{array}{l}813.96 \\
752.24\end{array}$ \\
\hline 3f & 1600.92 & 1651.07 & 3051.39 & - & $\begin{array}{l}815.89 \\
750.31 \\
709.80 \\
680.87\end{array}$ \\
\hline
\end{tabular}

The IR spectra of the compounds (5a-5f) revealed a sharp strong absorption band at $3300-3400 \mathrm{~cm}^{-1}$ that can be assigned with the presence of $\mathrm{NH}$ group and aromatic $\mathrm{CH}$ asymmetric and symmetric stretching vibration in the structure of ethyl carboxylates around $3100 \mathrm{~cm}^{-1}$. The aliphatic $\mathrm{CH}$ group showed a sharp absorption band around at $2900 \mathrm{~cm}^{-1}$ and another sharp strong absorption band was noticed at around $1560 \mathrm{~cm}^{-1}$ for $\mathrm{C}=\mathrm{N}$ group and 
the stretching frequency for $\mathrm{C}-\mathrm{N}$ group obtained around $1350 \mathrm{~cm}^{-1}$. The band near $1730 \mathrm{~cm}^{-1}$ for ester $\mathrm{C}=\mathrm{O}$ group. The IR spectrum values of compounds (5a-5f) are shown in Table 4.

Table 3. The IR spectrum values of compounds $\mathbf{4 a - 4 f}$

\begin{tabular}{|c|c|c|c|c|c|c|}
\hline Compound & $\begin{array}{c}\mathrm{NH} \\
\text { Stretching } \\
\mathrm{cm}^{-1}\end{array}$ & $\begin{array}{c}\mathrm{C}=\mathrm{C} \\
\text { Stretching } \\
\mathrm{cm}^{-1}\end{array}$ & $\begin{array}{c}\mathrm{C}=\mathrm{N} \\
\text { Stretching } \\
\mathrm{cm}^{-1}\end{array}$ & $\begin{array}{l}\text { Aromatic } \\
\text { Stretching } \\
\mathrm{cm}^{-1}\end{array}$ & $\begin{array}{c}\text { C-N } \\
\text { Stretching } \\
\mathrm{cm}^{-1}\end{array}$ & $\begin{array}{c}\text { Aromatic ring } \\
\text { Stretching } \\
\mathrm{cm}^{-1}\end{array}$ \\
\hline $4 a$ & 3329.14 & 1637.58 & 1554.63 & $\begin{array}{l}3067.17 \\
3197.96\end{array}$ & 1357.83 & $\begin{array}{l}756.10 \\
684.73\end{array}$ \\
\hline $4 b$ & 3327.21 & 1643.35 & 1562.34 & $\begin{array}{l}3042.60 \\
3162.50\end{array}$ & 1365.60 & $\begin{array}{l}754.17 \\
676.24\end{array}$ \\
\hline $4 c$ & 3319.49 & 1645.28 & $\begin{array}{l}1560.41 \\
1533.41\end{array}$ & $\begin{array}{l}3041.74 \\
3172.90\end{array}$ & 1350.17 & $\begin{array}{l}796.60 \\
773.46, \\
642.80\end{array}$ \\
\hline $4 d$ & 3302.15 & 1625.99 & $\begin{array}{l}1582.34 \\
1533.41\end{array}$ & $\begin{array}{l}3061.39 \\
3182.55\end{array}$ & 1350.17 & $\begin{array}{l}773.46, \\
750.31\end{array}$ \\
\hline $4 e$ & 3388.93 & 1620.92 & 1531.48 & 3176.76 & 1348.24 & $\begin{array}{l}771.53 \\
678.04\end{array}$ \\
\hline $4 f$ & 3300.20 & 1681.93 & 1534.41 & $\begin{array}{l}3045.60, \\
3182.55\end{array}$ & 1348.24 & $\begin{array}{l}773.46 \\
678.94\end{array}$ \\
\hline
\end{tabular}

Table 4. The IR spectrum values of compounds $\mathbf{5 a - 5 f}$

\begin{tabular}{|c|c|c|c|c|c|c|c|c|}
\hline Compound & $\begin{array}{l}\mathrm{NH} \\
\mathrm{cm}^{-1}\end{array}$ & $\begin{array}{l}\text { Ester } \\
\mathrm{C}=\mathrm{O} \\
\mathrm{cm}^{-1}\end{array}$ & $\begin{array}{l}\mathrm{C}-\mathrm{H} \\
\mathrm{cm}^{-1}\end{array}$ & $\begin{array}{l}\mathrm{C}=\mathrm{N} \\
\mathrm{cm}^{-1}\end{array}$ & $\begin{array}{l}\mathrm{C}-\mathrm{N} \\
\mathrm{cm}^{-1}\end{array}$ & $\begin{array}{c}\text { Aliphatic } \\
\mathrm{CH} \\
\mathrm{cm}^{-1} \\
\end{array}$ & $\begin{array}{c}\text { Aromatic } \\
\mathrm{CH} \\
\mathrm{cm}^{-1} \\
\end{array}$ & $\begin{array}{l}\text { Aromatic ring } \\
\text { stretching } \\
\mathrm{cm}^{-1}\end{array}$ \\
\hline $5 a$ & 3334.92 & 1735.93 & 1635.64 & 1556.55 & 1348.24 & $\begin{array}{l}2860.43 \\
2924.09\end{array}$ & $\begin{array}{c}3047.53,3 \\
199.91\end{array}$ & $\begin{array}{l}827.46 \\
759.95 \\
694.37\end{array}$ \\
\hline $5 b$ & 3327.21 & 1739.79 & 1643.35 & 1564.27 & 1367.53 & $\begin{array}{l}2852.72 \\
2920.23\end{array}$ & $\begin{array}{c}3056.16,3 \\
182.90\end{array}$ & $\begin{array}{l}754.17 \\
806.25\end{array}$ \\
\hline $5 c$ & 3435.22 & 1734.51 & 1648.84 & 1514.12 & 1342.06 & $\begin{array}{l}2843.61 \\
2910.17\end{array}$ & 3167.82 & 773.11 \\
\hline $5 d$ & 3442.94 & 1735.16 & 1653.27 & 1560.41 & 1384.89 & $\begin{array}{l}2838.90 \\
2917.30\end{array}$ & 3149.71 & 794.67 \\
\hline $5 e$ & 3394.72 & 1734.83 & 1604.77 & 1552.40 & 1396.46 & $\begin{array}{l}2827.45 \\
2908.31\end{array}$ & 3125.49 & 775.35 \\
\hline $5 f$ & 3307.92 & 1732.67 & 1622.13 & 1562.34 & 1354.03 & $\begin{array}{l}2819.93, \\
2903.63\end{array}$ & 3186.40 & 794.67 \\
\hline
\end{tabular}

The ${ }^{1} H$ NMR spectrum of compound $4 \boldsymbol{e}$

In the ${ }^{1} \mathrm{H}$ NMR of the compound $4 \mathrm{e}$ (Figure 2) shows that the signal at $5.3 \mathrm{ppm}$ is due to the presence of $\mathrm{NH}_{2}$ proton of pyrimidine moiety. The signal at $7.0 \mathrm{ppm}$ is attributed to $\mathrm{H} 5$ proton of pyrimidine moiety. The aromatic protons appeared in the range of 8.7 to $7.3 \mathrm{ppm}$.

The ${ }^{13} \mathrm{C} N M R$ spectrum of compound $4 \boldsymbol{e}$

In the ${ }^{13} \mathrm{C}$ NMR of the compound 4e, (Figure 3 ) the ${ }^{13} \mathrm{C}$ resonance at $166.34 \mathrm{ppm}$ is due to the presence of $\mathrm{C}-2$ carbon of pyrimidine moiety. The ${ }^{13} \mathrm{C}$ resonance at $163.66 \mathrm{ppm}$ is due to the presence of C-4 carbon of pyrimidine moiety. The ${ }^{13} \mathrm{C}$ resonance at $104.60 \mathrm{ppm}$ is due to the presence of $\mathrm{C}-5$ carbon of pyrimidine moiety. The ${ }^{13} \mathrm{C}$ resonance at $166.10 \mathrm{ppm}$ is attributed to C- 6 carbon of pyrimidine moiety. The resonance at $137.78 \mathrm{ppm}$ is assigned to C- $4^{1}$ carbon of 
phenyl ring. The aromatic carbons are appeared in the range of $128.95 \mathrm{ppm}$ to $124.12 \mathrm{ppm}$. The remaining ${ }^{13} \mathrm{C}$ signals at $130.52,133.25,134.9$ and $134.45 \mathrm{ppm}$ are ipso carbons.

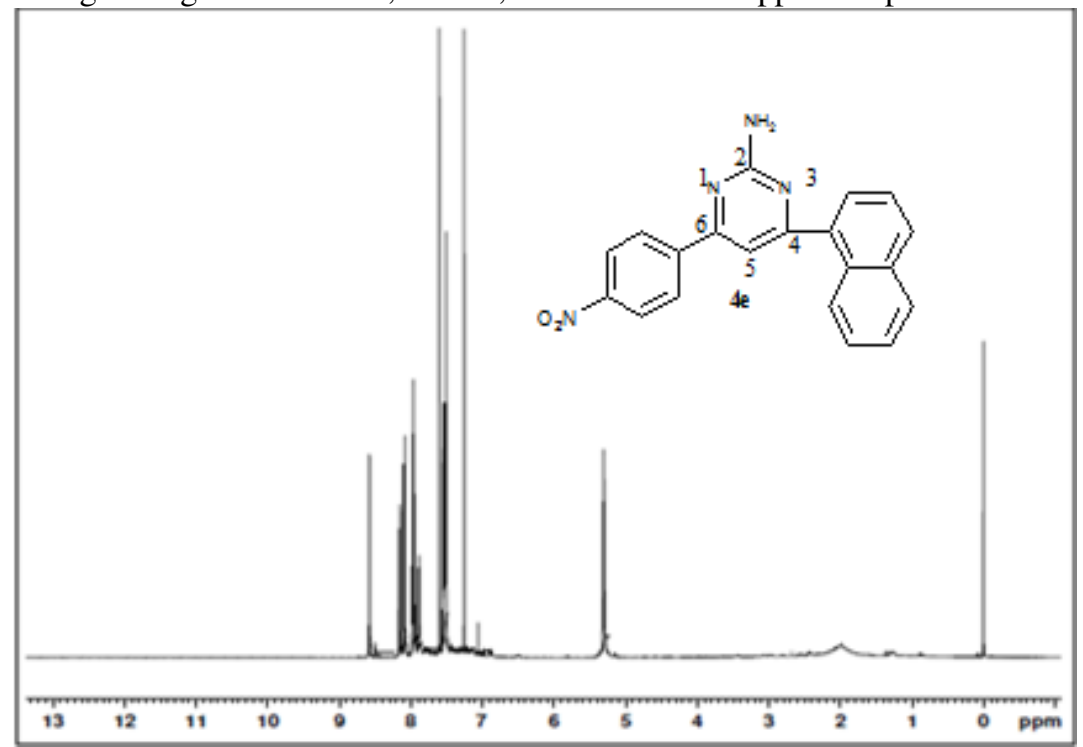

Figure 2. 1H NMR spectrum of compound $4 \mathrm{e}$

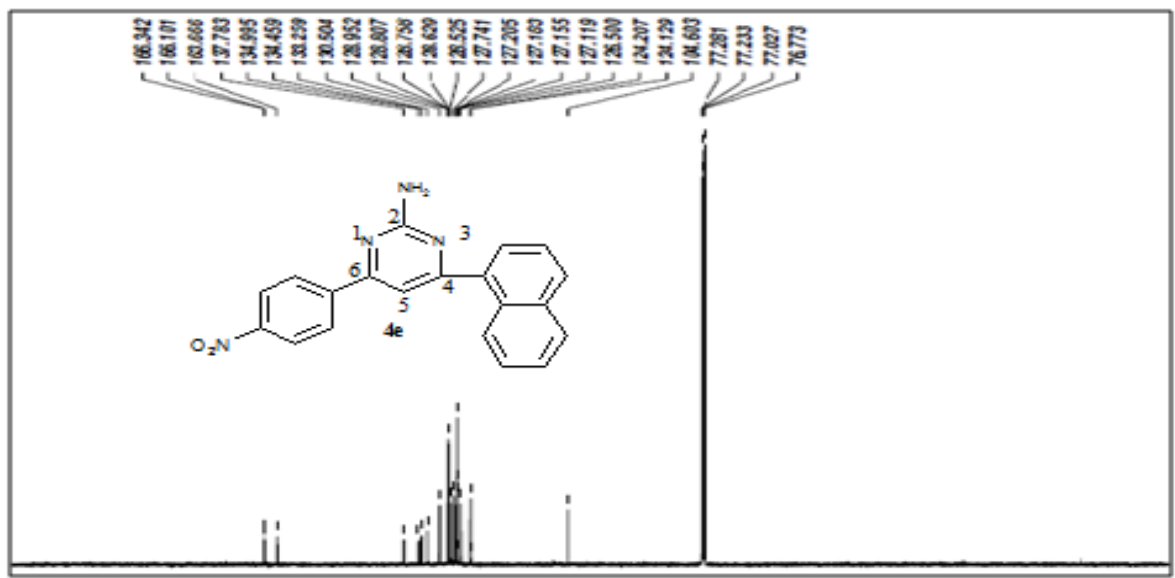

Figure 3. ${ }^{13} \mathrm{C}$ NMR spectrum of compound $4 \mathbf{e}$

\section{The ${ }^{1}$ H NMR spectrum of compound $5 \boldsymbol{e}$}

${ }^{1} \mathrm{H}$ NMR spectrum of compounds 5e (Figure 4) shows that the signal at $2.44 \mathrm{ppm}$ is assigned to $\mathrm{NH}$ proton of pyridine moiety. The triplet at $1.25 \mathrm{ppm}(\mathrm{J}=10 \mathrm{~Hz})$ is assigned to the ester methyl protons. The signal at $5.49 \mathrm{ppm}$ is due to the presence of ester methylene protons. The signal at $5.35 \mathrm{ppm}$ is assigned to methylene proton attached with the NH (imine) group. The aromatic naphthalene protons are appeared multiplet in the range of 7.49 to $8.16 \mathrm{ppm}$.

\section{The ${ }^{13}$ C NMR spectrum of compound $5 \boldsymbol{e}$}

${ }^{13} \mathrm{C}$ NMR spectrum of compound 5e (Figure 5) shows that the ${ }^{13} \mathrm{C}$ resonance at $166.37 \mathrm{ppm}$ is assigned to $\mathrm{C}-2$ carbon of pyrimidine ring. The ${ }^{13} \mathrm{C}$ resonance at $163.6 \mathrm{ppm}$ is assigned to 
C-4 carbon of pyrimidine ring. The ${ }^{13} \mathrm{C}$ resonance at $104.65 \mathrm{ppm}$ is due to the presence of $\mathrm{C}-5$ carbon of pyrimidine ring. The ${ }^{13} \mathrm{C}$ resonance at $166.13 \mathrm{ppm}$ is assigned to $\mathrm{C}-6$ carbon of pyrimidine ring. The ${ }^{13} \mathrm{C}$ resonance at $56.02 \mathrm{ppm}$ is due to the presence of ester methylene carbon. The ${ }^{13} \mathrm{C}$ resonance at $31.93 \mathrm{ppm}$ is assigned to methylene carbon attached with $\mathrm{NH}$ group. The ${ }^{13} \mathrm{C}$ resonance at $169.0 \mathrm{ppm}$ is assigned to ester carbonyl carbon. The aromatic carbons appeared in the range of 128.95 to $124.22 \mathrm{ppm}$. The remaining ${ }^{13} \mathrm{C}$ signals 130.51 , 133.26, 134.47, $134.97 \mathrm{ppm}$ are ipso carbons.

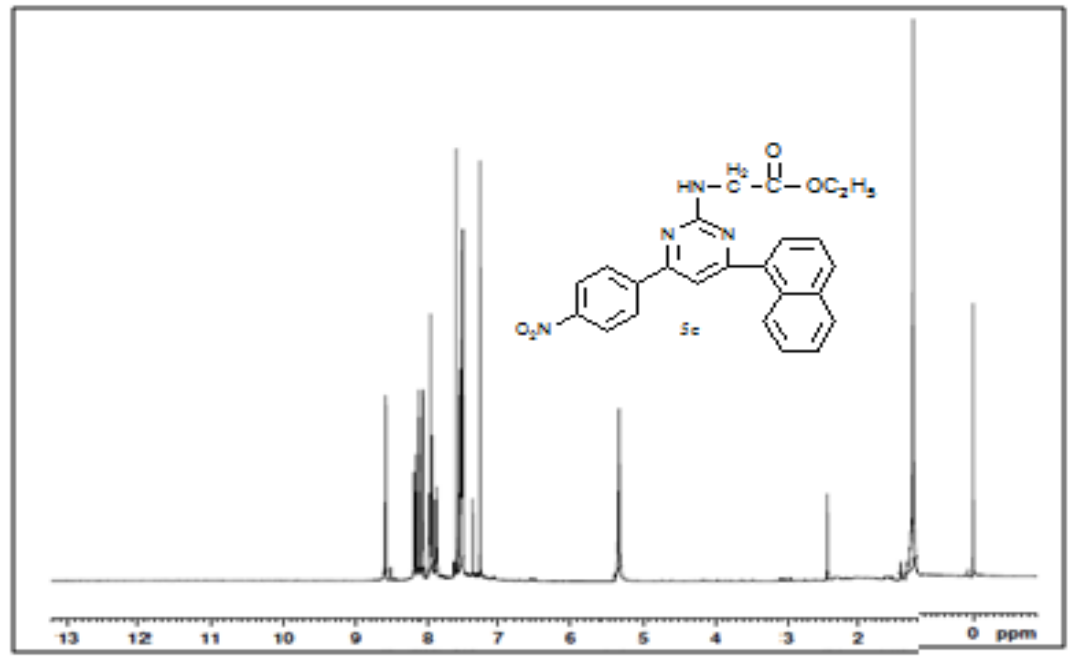

Figure 4. ${ }^{1} \mathrm{H}$ NMR spectrum of compound $\mathbf{5 e}$

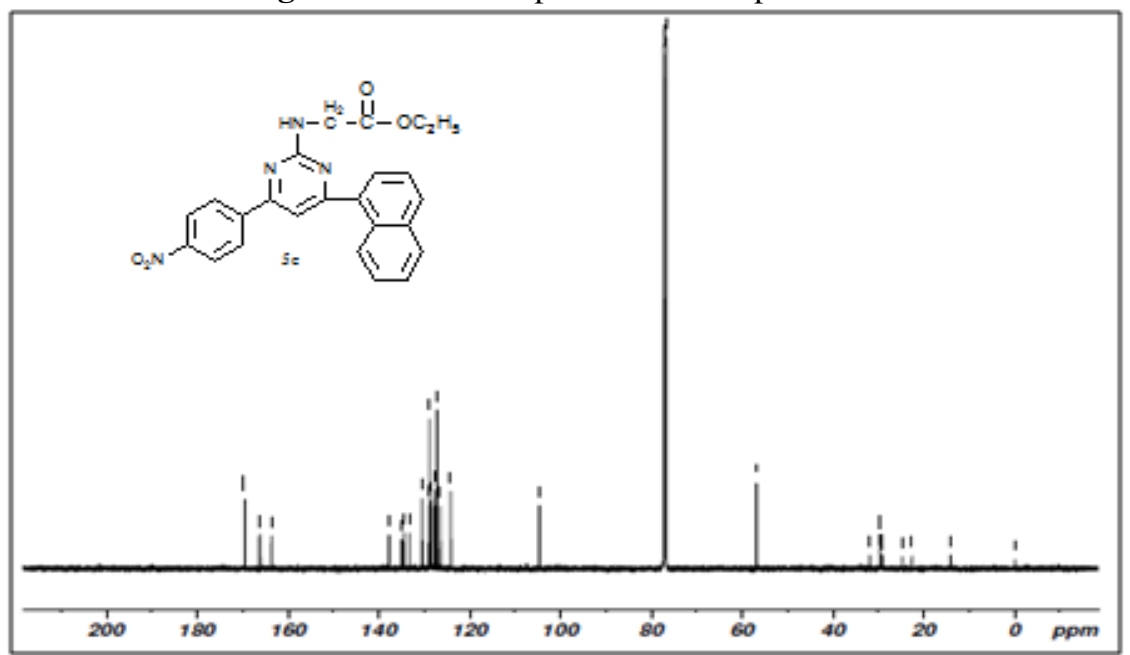

Figure 5. ${ }^{13} \mathrm{C}$ NMR spectrum of compound $\mathbf{5 e}$

\section{Antimicrobial activity}

All of our synthesised compounds (5a-5f) were tested for antimicrobial activity against the three test organisms are Staphylococcus epidermidis as an example of gram positive, Pseudomonas aeruginosa as an example of gram negative and a fungal organism of Candida albicans. Here ciprofloxacin used as a standard drugs. The agar disk diffusion method was applied for the 
determination of inhibition zone ( $\mathrm{mm}$ in diameter). From the result of antimicrobial activity of the synthesized compound, the electron donating methoxy substituted phenyl ring shows better zone of inhibition against the bacterial strain Staphylococcus epidermidis. The electron withdrawing chloro substituted phenyl ring shows good zone of inhibition against the bacterial strain Pseudomonas aeruginosa and the fungal strain Candida albicans. The results of antimicrobial activities of other synthesized compounds are shows in the below Table 5.

Table 5. Anti-microbial activity of the synthesized compounds (5a-5f)

\begin{tabular}{|c|c|c|c|c|c|c|c|c|c|c|c|c|}
\hline \multirow{4}{*}{ Sample } & \multicolumn{12}{|c|}{ Zone of Inhibition ( $\mathrm{mm}$ in diameter) } \\
\hline & \multicolumn{8}{|c|}{ Anti-bacterial } & \multicolumn{4}{|c|}{ Anti-fungal } \\
\hline & \multicolumn{4}{|c|}{$\begin{array}{l}\text { Staphylococcus } \\
\text { epidermidis }\end{array}$} & \multicolumn{4}{|c|}{$\begin{array}{c}\text { Pseudomonas } \\
\text { aeruginosa }\end{array}$} & \multicolumn{4}{|c|}{ Candida albicans } \\
\hline & $\overline{2.5 \mu}$ & $5.0 \mu$ & $.5 \mu$ & $0 \mu$ & $.5 \mu$ & $5.0 \mu$ & $.5 \mu$ & $10 \mu$ & $5 \mu$ & $5.0 \mu$ & $.5 \mu$ & $10 \mu \mathrm{L}$ \\
\hline $5 \mathrm{a}(\mathrm{H})$ & 6 & 9 & 10 & 11 & 7 & 9 & 11 & 13 & 6 & 8 & 9 & 11 \\
\hline $5 b\left(\mathrm{CH}_{3}\right)$ & 6 & 10 & 11 & 13 & 8 & 10 & 12 & 13 & 6 & 9 & 11 & 13 \\
\hline $5 \mathrm{c}\left(\mathrm{OCH}_{3}\right)$ & 8 & 9 & 11 & 14 & 5 & 7 & 12 & 15 & 8 & 11 & 13 & 14 \\
\hline $5 \mathrm{~d}(\mathrm{Cl})$ & - & 7 & 10 & 12 & - & 12 & 13 & 19 & - & 12 & 13 & 16 \\
\hline $5 \mathrm{e}\left(\mathrm{NO}_{2}\right)$ & 8 & 10 & 12 & 13 & 10 & 11 & 14 & 16 & 9 & 10 & 11 & 13 \\
\hline $5 \mathrm{f}(\mathrm{Br})$ & 7 & 9 & 10 & 12 & 9 & 11 & 13 & 17 & 7 & 9 & 10 & 12 \\
\hline
\end{tabular}

\section{Conclusion}

The titled compounds were synthesized by esterification reactions. The synthesized compounds were characterized by using IR, ${ }^{1} \mathrm{H}$ NMR and ${ }^{13} \mathrm{C}$ NMR spectrum. Spectral and chemical analysis supported to identify the expected structural formula of the compounds. These compounds were subjected to antimicrobial activity. From the results, the electron withdrawing chloro substituted compound have an excellent inhibition against the Pseudomonas aeruginosa and Candida albicans and the electron donating methoxy substituent have a greater inhibition against the Staphylococcus epidermidis.

\section{References}

1. Avila H P, Smania E F A, Monache F D and Smania A J, Bioorg Med Chem., 2008, 16(22), 9790-9794; DOI:10.1016/j.bmc.2008.09.064

2. Liu Yu, Sun Xiao, Yin Da and Yuan Fang, Res Chem Intermed., 2013, 39, 10371048; DOI:10.1007/s11164-012-0665-Z

3. Sortino M, Delgado P, Juarez S, Quiroga J, Abonia R, Insuasty B, Nogueras M, Rodero L, Garibotto F M, Enriz R D and Zacchino S A, Bioorg Med Chem., 2007, 15(1), 484-494; DOI:10.1016/j.bmc.2006.09.038

4. Vargas M L Y, Castelli M V, Kouznetsov V V, Urbina G J M, Lopez S N, Sortino M, Enriz R D, Ribas J C and Zacchino S, Bioorg Med Chem., 2003, 11(7), 1531-1550; DOI:10.1016/S0968-0896(02)00605-3

5. Gopalasamy A, Shi M, Golas J, Vogan E, Jacob J, Johnson M, Lee F, Nilakantan R, Petersen R, Svenson K, Chopra R, Tam M, S, Wen Y, Ellingboe J, Arndt K and Boschelli F, J Med Chem., 2008, 51(3), 373-379; DOI:10.1021/jm701385c

6. Jain $\mathrm{M}$ and Kwon C H, J Med Chem., 2003, 46(25), 5428-5436; DOI:10.1021/jm020581y

7. Lagoja I M, J Med Chem., Biodiversity, 2005, 2(1), 1-50; DOI:10.1002/cbdv.200490173

8. Sehan, C A, Lee D, Goodman K B, Wang G Z and Viet A Q, Chem Abstr., 2006, 144, 150383. 
9. Wagner E, Al-Kadasi K, Zimecki M and Sawka D, Eur J Med Chem., 2008, 43(11), 2498-2504; DOI:10.1016/j.ejmech.2008.01.035

10. Wang S Q, Fang L, Liu X J and Zhao K, Chinese Chem Lett., 2004, 15(8), 885-888.

11. Khalifa N M, Ismail N S and Abdulla M M, Egypt Pharm J., 2005, 4, 277-288.

12. Ezhilarasi M R, Prabha B and Prabakaran S, J Applicable Chem., 2014, 3(5), 1929-1935.

13. Henrie Robert N, Peake Clinton J and Cullen Thomas G, Chem Abstr., 1998, 129, 16136s.

14. Sadanandan Y S, Shetty N M and Diwan P V, Chem Abstr., 1990, 117, 7885k.

15. Khalafallah A K, Abd-El Latif F M and Salim M A, Asian J Chem., 1993, 5(4), 988-994.

16. Arvanitis A G, Gilligan P J G, Chorvat R J, Cheeseman R S, Christos T E, Bakthavatchalam R, Beck J P, Cocuzza A J, Hobbs F W, Wilde R R G, Arnold C, Chidester D, Curry M, He L, Hollis A, Klaczkiewicz J, Krenitsky P J, Rescinito J P, Scholfied E, Culp S, De Souza E B, Fitzgerald L, Grigoriadis D, Tam S W, Wong Y N, Huang S M and Shen H L, J Med Chem., 1999, 42(5), 805-818; DOI:10.1021/jm980222w

17. Kulandhaivel M and Palaniswamy M, International J Pharma Biological Archives, 2012, 3(3), 563-568. 